\title{
How many observation days are needed to reliably describe bird migration?
}

\author{
Hur många observationsdagar behövs för att tillförlitligt beskriva fågelflyttning?
}

\author{
ANTTI TANSKANEN, RAUNO A. YRJÖLÄ, ULRIKE BAUM, SAKARI TANSKANEN, \\ JÖRGEN ERIKSSON
}

\begin{abstract}
The total number of migrating birds is needed, for example, to estimate collisions risk as part of the assessment process for wind-power parks. This estimation is often based on a small sample of observation days, making estimates uncertain. To determine the number of days needed to obtain reliable figures we used observations of migrating birds obtained from the Signilskär bird observatory, Alland, Finland during the autumn seasons from 2009 to 2013 . We sampled 1-14 days during each 14 day time window and used linear extrapolation and Poisson regression with weather covariates to estimate the total number of migrating birds and distribution of estimates. We calculated the head-wind and side-wind components according to the species' most common flight directions. We found that observations should cover at least $90 \%$

of the migration period to obtain precise results and $70-90 \%$ to obtain results sufficiently reliable to use in practice. Linear extrapolation is the best model for small samples. The larger the proportion of days observed, the better is Poisson regression with weather covariates.

Antti Tanskanen, Karolinska Institutet, Stockholm, Sweden,Email: antti.tanskanen@ki.se

Rauno A. Yrjölä, Environmental Research Yrjölä Ltd, Klaukkala, Finland, Email: rauno.yrjola@yrjola.fi Ulrike Baum, University of Turku, Turku, Finland Sakari Tanskanen, Aalto University, Helsinki, Finland Jörgen Eriksson, Ålands fägelskyddsförening, Mariehamn, Aland, http://www.fagelskyddsforeningen.ax/
\end{abstract}

Received 20 December 2017, Accepted 11 June 2018, Editor: Jonas Waldenström

\section{Introduction}

The effects of artificial structures such as roads, electric wires and wind turbines on animal populations have been extensively studied. Several investigations have shown that these structures may negatively affect populations (Avery 1979, Coffin 2007, Fahrig \& Rytwinski 2009). During recent decades the impacts of wind-power plants on birds, have been widely discussed by ornithologists and conservationists, and a publication compilation and several scientific articles have been written about this subject (Drewitt \& Langston 2006, Hüppop et al. 2006, Lucas et al. 2007, Stewart et al. 2007, Krijgsveld et al. 2009, Furness et al. 2013).

Large soaring birds of prey are vulnerable, but other bird species also migrate along coastal routes where power plants are usually installed.

The general problems involved in bird migration studies have been discussed in several summary publications (Alerstam 1982, Baker 1984, Berthold 1993). Estimating the number of migrating birds with conventional observation and sampling methods is not an easy task. Visible migrating birds can be observed and counted fairly well under ideal conditions, i.e. when the migration occurs at low altitudes and the visibility is favourable. However, some bird species migrate during the night or at such high altitudes that observers cannot detect them, and radar or other techniques are needed. The birds' migratory behaviour is also dependent on whether they are long- or short-distance migrants. Many long-distance migrants arrive late in spring, leaving early in autumn and migrate during the night. This applies especially to insectivorous species.

The migration of most species lasts several weeks within a season. Only for a few species, such as cranes, does the migration peak last only a few days when the weather conditions are favourable. With some species, such as many water birds, the migration period can last several weeks, and the weather may significantly affect the intensity and duration of the migration.

To reliably estimate the number of birds throughout the migration period, continuous observation should be used from the beginning to the end of the 
migration. Usually, this is not possible other than in bird observatories that are occupied continuously. Alternatively, the number of migrants can be estimated by observing birds within certain time periods. How many observation days or hours are needed to obtain reliable estimates of the number of migrating birds and how often the observations should be made during migration to minimize effort and maximize accuracy are questions that have remained unanswered so far. Views on the number of observation days needed have varied widely. A review of wind farm bird studies in North America showed that there is a need to standardize surveying methods; observation times and intervals have varied widely among studies, and the observation effort per land area was usually lower when wind parks were larger (Smallwood 2017).

Conservationists usually call for increased numbers of observation days, while the builders of wind-power parks or other infrastructures prefer fewer observation days to minimize costs. In 2016, the Ministry of the Environment in Finland (Ympäristöministeriö 2016) published a recommendation for the number of observation days needed for the spring and autumn migration periods. The recommendation states a minimum of 30 days of observation during migration periods in southern Finland and 20 days in northern Finland. These recommendations may have been based more on precautionary principles rather than on scientific studies.

Migration data are often collected by volunteer birdwatchers who irregularly visit observation sites, i.e. sites that are known to be the best places for migration observation in the region. Thus, the migration data are sparse and do not always give an overall picture of migration. Additionally, weather conditions and working days during the week may affect observation intensity, and observations during fine weather on weekends may be carried over to weekdays and periods of rough weather. Observation intensity may vary between years, which may make it difficult to detect reliable patterns and timing of migration and number of migrants. Observations may not cover the area that is under investigation, and interpolating local migration intensity from nearby places is problematic.

Environmental Impact Assessment (EIA) legis-

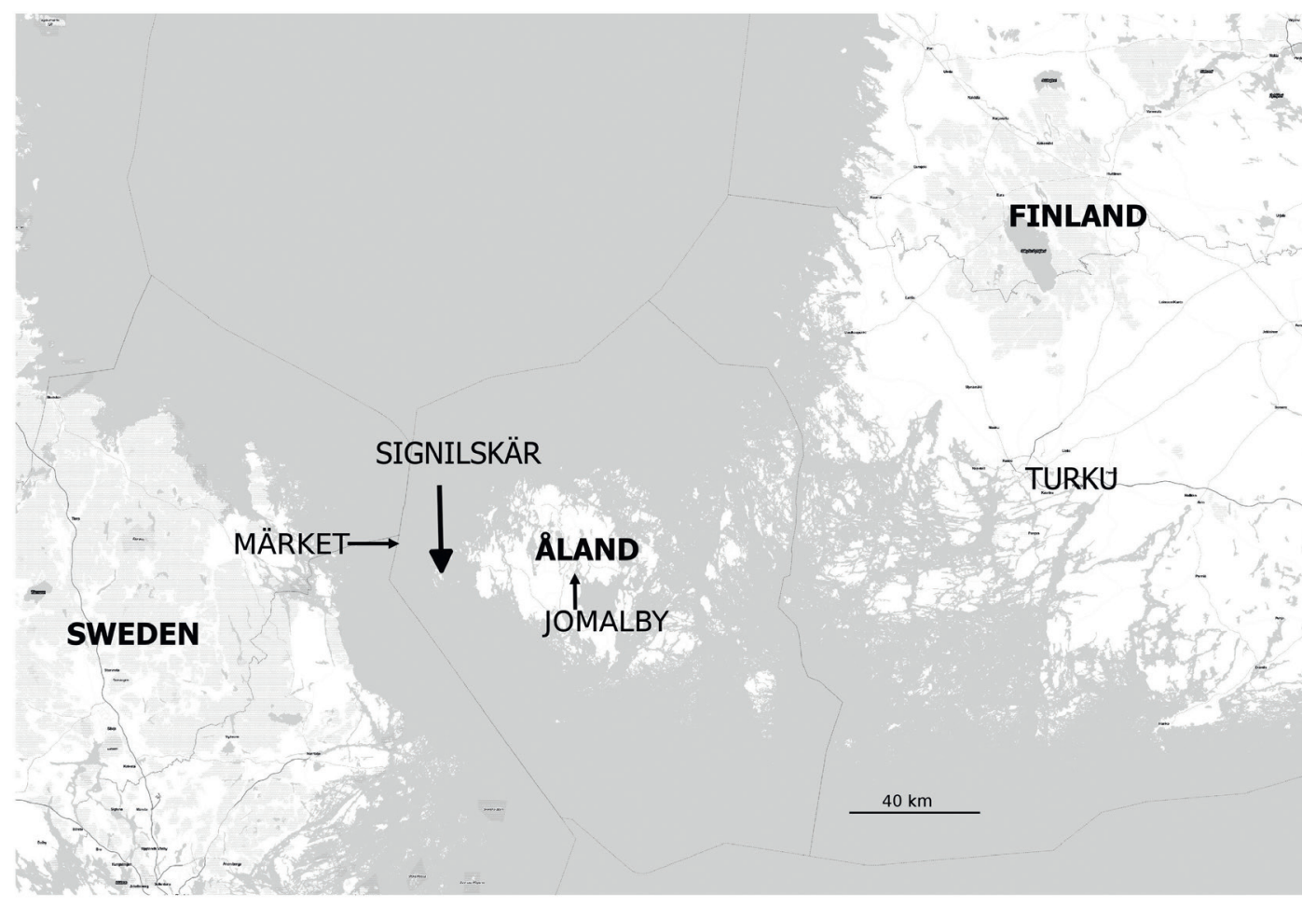

Figure 1. Signilskär is located between Åland and Sweden (map source OSM.org).

Signilskär ligger mellan Aland och Sverige. 
lation forces those who perform or plan tasks that may alter the environment to evaluate the possible risks to the environment. One example is wind power, since wind turbines may kill migratory birds, and thus the location and arrangement of turbines are crucial factors that impact collision risks. To evaluate the risks, bird migration density is usually monitored in the area where wind- turbine construction has been planned. This needs a microscale estimation of migration behaviour that is usually not known beforehand. In larger areas, observations are made at several points, and observation is usually done following a predetermined sampling scheme.

Limited knowledge is available on the number of observation days required to obtain an estimate of migratory bird counts throughout the migration season with an acceptable level of certainty. There are no definitions of how accurate migration data should be in EIA studies in Finland, for example. Thus, this acceptable level is dependent on who is asked, i.e. authorities, industry or researchers. One recent study from Massachusetts, using migration data from 1969 to 2012, analysed this problem by addressing the question of how much time was needed to describe the changes detected with observations from 5-day weeks throughout the migration season (Stegman et al. 2017). The authors showed that with $60 \%$ sampling intensity it was possible to detect the same changes as in all the original data. The aim of this study is to evaluate sample size, sampling and extrapolation methods and how they affected the reliability of estimates. We analysed the observation material collected at the Signilskär bird observatory and attempt to estimate how large the observation sample should be to ensure that it describes the number of migrating birds throughout the season with sufficient reliability. We compare linear extrapolation with model- ling migration according to weather conditions. We also investigate whether modelling migration according to weather conditions in a single year can be used for estimating migration in some other year with a sample of migration data from that year.

\section{Materials and methods}

\section{Study area}

The bird observations were made at the Signilskär bird observatory $\left(60^{\circ} 11.6^{\prime} \mathrm{N}, 19^{\circ} 20.5^{\prime} \mathrm{E}\right)$ (Figure 1). It is the oldest such observatory in Finland and is situated between the Aland Islands (distance 10 $\mathrm{km})$ and the coast of Sweden $(30 \mathrm{~km})$. Many bird species that migrate during the day use this route to avoid crossing the open sea, especially during the autumn migration. These species include crows, finches and many birds of prey. Signilskär is fairly small, about $1.7 \mathrm{~km}$ long and almost $1 \mathrm{~km}$ wide. Several small deciduous woods are found on the island, while other areas comprise mainly various meadow biotopes, open rocks and seashore bushes.

\section{Bird observations}

We used records of autumn migration observations from the years 2009 to 2013. The number of observation days varied from 36 (2010) to 51 (2013) (Table 1). In total, the data comprised 226 days, during which 1408146 migratory birds were observed. The number of taxonomic units (species, subspecies or wider units such as 'large raptor') varied from 157 in 2013 to 206 in 2010 (Table 1). The observations began at the earliest on 20 August (in 2010) and ended at the latest on 3 November (in 2013). A day's observation period began at sunrise and lasted at least 3 hours. Often, this obligatory morning period was extended to 5-6 h, depend-

Table 1. Observation dates, number of birds observed and number of taxa.

Observationsperioder, antal observationsdagar, antal observerade fåglar och antal taxonomiska enheter.

\begin{tabular}{rcccr}
\hline Year & $\begin{array}{c}\text { Dates } \\
(\text { dd.mm })\end{array}$ & Observation days & $\begin{array}{c}\text { Total number of } \\
\text { birds observed }\end{array}$ & $\begin{array}{c}\text { Number of } \\
\text { taxonomic units }\end{array}$ \\
\hline 2009 & 19.-25.8. and 19.9.-31.10. & 49 & 134271 & 168 \\
2010 & $28.8 .-1.9$. and 25.9.-30.10. & 36 & 184405 & 206 \\
2011 & $27 .-31.8,5 .-16.9$. and 1.-29.10. & 46 & 256022 & 173 \\
2012 & $15.9 .-28.10$. & 44 & 451820 & 166 \\
2013 & $14.9 .-3.11$. & 51 & 381628 & 157 \\
\hline
\end{tabular}


ing on the migration intensity, i.e. if the migration continued the observation was prolonged. Migrating birds were observed with binoculars and telescopes, and the observations were marked in the field on paper forms. The data recorded included time, species, number of birds, migration direction and distance from the observation point. We used the daily sum of the bird observations per species and, thus, we do not have individual directions of migratory birds or timing of individual birds.

\section{Weather data}

Weather data (wind speed and direction, precipitation) were recorded by the Finnish Meteorological Institute's two closest weather stations (see fmi.fi). The wind measurements were taken at the Hammarland Märket lighthouse (60 $60^{\circ} 18.1^{\prime} \mathrm{N} 19^{\circ} 7.9^{\prime}$ E), $17 \mathrm{~km}$ northwest of the Signilskär bird observatory. The predominant wind direction was the southwest, meaning a headwind for most of the autumn migration. We used a 10-min average wind speed and direction at 6:00 (Coordinated Universal Time UTC) in the morning. This selection was made, because we only had daily sums for migration. The daily precipitation (rain) data originated from Jomala Jomalby $\left(60^{\circ} 10.7^{\prime} \mathrm{N} 19^{\circ} 59.2^{\prime} \mathrm{E}\right), 36$ $\mathrm{km}$ east of Signilskär (Figures 1 and 2).

\section{Modelling migration}

Migration data preparation

We distinguished between five groups of species, i.e. all birds, water birds (European Union for Bird Ringing EURING < 2300) (see EURING codes 2000: http://www.euring.org/data-and-codes/euring-codes), nonwater birds (EURING $\geq 2300$ ), crows (EURING 15 600-15 749) and finches (EURING 16 360-16 389). 'All birds' also included unidentified birds that could not be classified in the other groups. We calculated head-wind, tail-wind and side-wind components for each observation (species and day), ignoring the migrating birds' own speed. Therefore, we assumed that land birds passing Signilskär were heading towards the west and other birds (water birds, gulls, waders, auks; EURING code $0-2300$ and 4500-6560 towards the

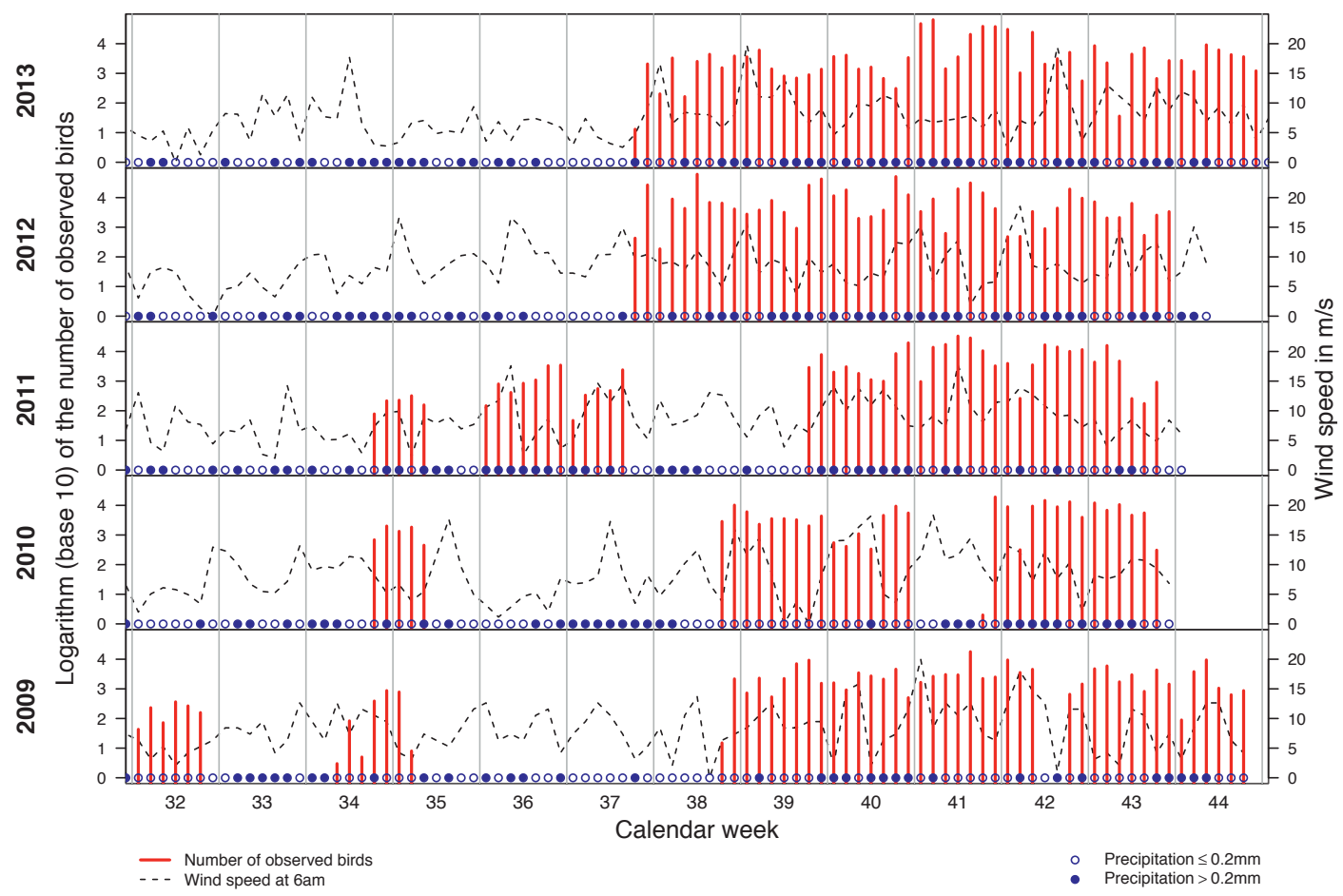

Figure 2. Weather conditions and bird observations 2009-2013 at Signilskär bird observatory.

Väderförhållanden och fågelobservationer 2009-2013 på Signilskär fågelstation. 
south. The wind components were categorized into three groups: light $(\leq 3 \mathrm{~m} / \mathrm{s})$, medium $(>3 \mathrm{~m} / \mathrm{s}$ and $\leq 9 \mathrm{~m} / \mathrm{s})$ and strong wind $(>9 \mathrm{~m} / \mathrm{s})$. We used two rain variables, rain on the index day and rain on the previous day, each categorized into two classes, no rain (precipitation $\leq 0.2 \mathrm{~mm}$ ) and rain (precipitation $>0.2 \mathrm{~mm}$ ). We grouped the autumn season into 14-day windows, beginning with weeks 35 and 36 in late August and ending with weeks 43 and 44 in early November.

\section{Stratified sampling}

To obtain a value that could be interpreted as the total estimate of migration intensity, we selected only those days of a season in which the bird observatory was occupied and migration documented. First, these days were numbered consecutively, independent of their timing, although keeping their order within the season. Subsequently, these days were divided into distinct 14-day windows, beginning with the first 14 days and ending with the last complete set of 14 days. In case the number of observation days in a season was not a multiple of 14, the remaining days not assigned to a time window were not included in the simulation analyses. The 14-day code (35-36 .. 43-44) was assigned to those 14-day periods in which most of the days belonged. Ultimately, we drew either a random or a clustered (continuous days) sample of 1-14 days from each complete set of 14 days. This random sample of days represented the observation days and the others the unobserved days, but here we refer to them as unsampled days, since birds were actually observed. These 14-day periods were selected to ensure coverage of bird observations throughout the season and allow windows of sufficient length to obtain accurate division of time.

\section{Statistical models}

To estimate the total number of migrating birds, we used two types of statistical regression model, linear extrapolation and Poisson regression, to model the migration density, depending on weather conditions and calendar time. First, we used linear regression with no explanatory variables. If we denote $\mathrm{N}_{\text {obs }}$ the observed number of birds and $\mathrm{N}_{\text {tot }}$ the estimated total number of birds, $\mathrm{T}_{\text {obs }}$ the observation time and $\mathrm{T}_{\text {tot }}$ the total time, we obtain equation (1),

$\mathrm{N}_{\text {tot }}=\left(\mathrm{T}_{\text {tot }} / \mathrm{T}_{\text {obs }}\right) \mathrm{N}_{\text {obs }}$

i.e. linear extrapolation over unsampled time. Since we used the same sample size in each 14-day window, this ratio of observation days is constant over the time windows, and the observed number of birds is multiplied by the ratio; e.g. with observations of 3 days from each 14-day window, the multiplier is $14 / 3=4.67$. This is the simplest model that extrapolates number of birds over unobserved time.

In our second and third approaches, we used Poisson regression models. Let's denote the logarithm of the number of birds observed (Nlog) and the weather variables of that day (headwind, tailwind, sidewind, rain, rain previous day), then the time in the season on the respective day of interest (14-day calendar time) is WT. The equation is then (2) $N l o g=$ intercept $+\beta^{\prime} W T$, where intercept is the migration intensity under reference conditions (light wind, no rain, calendar weeks $41-42$ ), $\beta$ the coefficient vector and WT the binary variable vector $(0 / 1)$ of each weather and time category. The wind components are also dependent on the birds' assumed flight direction, as described earlier.

In the second approach, we built the Poisson model, based on the data from the sampled days in each simulation, i.e. the regression coefficients may differ between the simulations, depending on the sampled days. The log number of migrating birds on an unsampled day was estimated, using values of regression covariates associated separately for each day's weather conditions and summing up the exponent-transformed results from each day. For example, if 5 days of each 14-day window were sampled, the regression coefficients (weather) were calculated, based on this sample, and these coefficients were used to calculate the estimated migration intensity for the remaining 9 days in each 14-day window. In the third approach, we built the Poisson model, based on the migration and weather data from all observation days for each year separately (Table 3 ). With these coefficients, we estimated the number of migrating birds in the previous year (estimate in 2009 with coefficients from 2010) and similarly the following year. This was done by fitting the model covariates on unsampled days as in the second approach. Finally, the total number of migratory birds was calculated as the sum of the estimated number of birds on unsampled days and the birds counted on sampled days.

\section{Simulations with the resampling technique}

We simulated the effect of shorter observation time with the resampling technique. One simulation consisted of sampling a fixed number of days from each 14-day window, selecting observations of one bird group for these selected days. We applied the models (one of three described earlier) to the 
Table 2. Number of days needed for sampling from a 14-day time window to yield $95 \%$ of the simulated migration estimates with $10 \%, 30 \%$ and $50 \%$ marginal error of the total number of migrating birds observed. The underlying statistical models were a) random selection of days and linear extrapolation, b) selection of clustered, continuous days and linear extrapolation, c) random selection of days and Poisson regression with weather covariates based on the days selected.

Antal stickprovsdagar som behövs ur ett fjortondagarsfönster för att nå 95\% av den simulerade skattningen med 10\%, 30\% och $50 \%$ marginalfel för totala antalet observerade fåglar. Underliggande modeller var a) slumpvis valda dagar och linjär extrapolering, b) sammanhängande dagar och linjär extrapolering, c) slumpvis valda dagar och Poisson-regression med vädervariabler.

\begin{tabular}{|c|c|c|c|c|}
\hline \multirow{2}{*}{$\begin{array}{l}\text { Original data } \\
\text { Species group }\end{array}$} & \multirow[b]{2}{*}{$\begin{array}{l}\text { Individuals } \\
\text { observed }\end{array}$} & \multicolumn{3}{|c|}{$\begin{array}{l}\text { Observation days needed in 14-day windows within different } \\
\text { error limits and } 95 \% \text { of simulations within limits }\end{array}$} \\
\hline & & $\begin{array}{l}10 \% \text { error } \\
\mathrm{a} / \mathrm{b} / \mathrm{c}\end{array}$ & $\begin{array}{l}30 \% \text { error } \\
\mathrm{a} / \mathrm{b} / \mathrm{c}\end{array}$ & $\begin{array}{l}50 \% \text { error } \\
\mathrm{a} / \mathrm{b} / \mathrm{c}\end{array}$ \\
\hline All birds & 1305428 & $14 / 14 / 14$ & $9 / 11 / 11$ & $6 / 8 / 9$ \\
\hline Water birds & 136894 & $14 / 14 / 14$ & $10 / 10 / 12$ & $7 / 8 / 11$ \\
\hline Nonwater birds & 1162298 & $14 / 14 / 14$ & $10 / 11 / 11$ & $6 / 8 / 11$ \\
\hline Crows & 519977 & $14 / 14 / 14$ & $11 / 14 / 13$ & $9 / 12 / 12$ \\
\hline Finches & 236205 & $14 / 13 / 14$ & $14 / 11 / 14$ & $11 / 10 / 13$ \\
\hline
\end{tabular}

unsampled days to estimate the number of migratory birds for unsampled days. This was repeated 10000 times to ensure a covering set of different days to be in the simulation. In all, we repeated the sampling and modelling steps 22.4 million times, i.e. we ran 10000 simulations for each year, combination of species group, number of days selected from a 14-day-window, sampling strategy and sta- tistical model. The median of these 10000 simulated estimates was interpreted as the estimate of the total number of migratory birds.

Finally, we calculated the number of days needed to observe in each 14-day window to obtain an estimate that deviated less than $10 \%, 30 \%$ and $50 \%$ from the observed total number of migrating birds with $95 \%$ probability. This was calculated from all
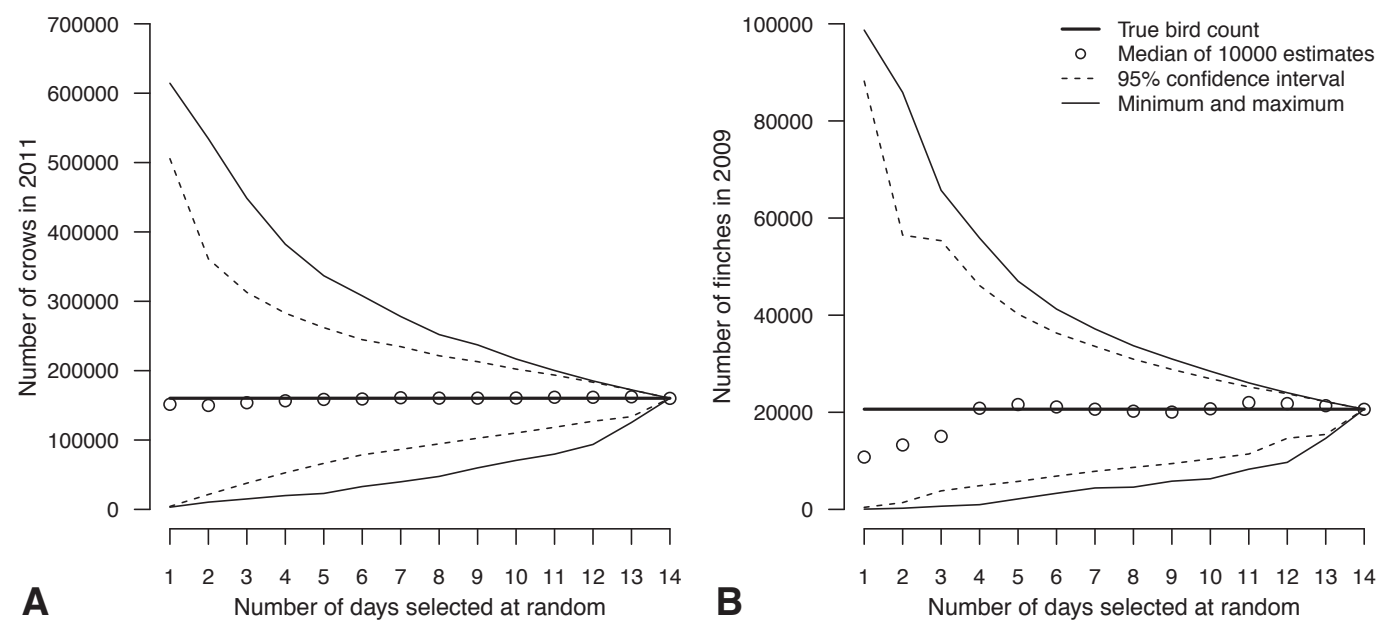

Figure 3. Results from simulating 140000 stratified random samples estimating the migration of (A) crows (Hooded Crow Corvus corone cornix L., Eurasian Jackdaw C. monedula L., Rook C. frugilegus L. and C. L. sp.) in 2011 and (B) finches (Chaffinch Fringilla coelebs L., Brambling F. montifringilla L. and F. L. sp.) in 2009 based on linear extrapolation. Resultat från simulering av 140000 slumpvisa stickprov för skattning av flyttningen av (A) kråkfåglar (gråkråka, kaja, råka och obestämda) 2011 samt (B) finkfåglar (bofink, bergfink och obestämda) 2009 med linjär extrapolering. 
Table 3. Exponent-transformed Poisson model coefficients for the years 2009-2013 and all birds combined. Reference categories (with value 1) are light winds, no rain and 14 days covering weeks 41-42. NA indicates the absence of observations. Exponenttransformerade koefficienter från Poisson-modell för åren 2009-2013 och med alla fäglar kombinerade. Referenser med värde 1 är svag vind, inget regn och 14 dagar veckorna 41-42. NA anger avsaknad av observationer.

\begin{tabular}{|c|c|c|c|c|c|}
\hline Covariates & 2009 & 2010 & 2011 & 2012 & 2013 \\
\hline Intercept & 2114.1 & 2411.2 & 7553.5 & 8570.1 & 6734.5 \\
\hline medium headwind & 1.99 & 2.17 & 1.95 & 0.96 & 1.33 \\
\hline medium tailwind & 0.96 & 0.95 & 0.28 & 0.69 & 0.31 \\
\hline strong headwind & 0.93 & 0.3 & 0.12 & 2.4 & 0.05 \\
\hline strong tailwind & 0.82 & 1.2 & 0.49 & 0.25 & 0.66 \\
\hline rain index day & 0.77 & 1.18 & 0.77 & 0.45 & 1.43 \\
\hline rain previous day & 0.38 & 1.2 & 0.85 & 0.75 & 0.45 \\
\hline medium sidewind & 0.91 & 1.07 & 0.59 & 1.59 & 2.89 \\
\hline strong sidewind & 1.74 & 0.82 & 0.97 & 0.87 & 1.09 \\
\hline Weeks 35-36 & 0.1 & 0.21 & 0.04 & NA & NA \\
\hline Weeks 37-38 & 0.27 & NA & 0.13 & 0.92 & 0.09 \\
\hline Weeks 39-40 & 0.8 & 1.29 & 0.83 & 1.33 & 0.13 \\
\hline Weeks 43-44 & 0.77 & 1.18 & 0.65 & 0.32 & 0.25 \\
\hline
\end{tabular}

5 years, 10000 simulations each year, and $95 \%$ of these amounted to 47500 simulation estimates. We calculated the minimum number of days needed to obtain estimates that were within the $\pm 10 \%, 30 \%$ and $50 \%$ boundaries from the observed number of migratory birds in the corresponding year to fulfil this cumulative $95 \%$ probability over all 5 years.

\section{Results}

Table 2 presents the number of days needed to achieve estimates within a $10 \%, 30 \%$ and $50 \%$ marginal error of the total number of migrating birds observed in $95 \%$ of the simulations. In practice, all days must be sampled to achieve results within the $10 \%$ marginal error. In tolerating a higher marginal error of up to $50 \%$, only $50-70 \%$ of the days are needed, depending on the bird species. When linear extrapolation was used, random selection of days was more efficient than selection of clustered, continuous days. The species group of finches formed an exception, because selecting continuous days appeared to be more efficient than selecting days randomly. Moreover, linear extrapolation required fewer observation days to generate a result within a particular error margin than a Poisson model, which utilised the migration year's weather data, except for the crow taxa. For crows, the Poisson model performed slightly better than linear extrapolation, based on clustered days, although the linear extrapolation based on randomly selected days best predicted the number of migrating birds.

Figure 3 depicts how the variation in the results based on linear extrapolation converges fairly smoothly. After 4-5 out of 14 days, the estimate improved constantly with each additional day.

In modelling migration based on the weather data from the observation days themselves, the Poisson model used in the second approach performed poorly when only a few days were selected (Figure 4). To achieve reliable estimates, more than half of the 14 days must be sampled. However, when almost all days were sampled, this method was more 
accurate than linear extrapolation.

Table 3 shows the regression coefficients yielded by Poisson regression analyses in modelling migration, given the weather data for each year from 2009 to 2013 (third approach). The general picture suggests that medium headwinds were associated with higher numbers of migrating birds than those observed on a standard day, while the other wind conditions were associated with lower numbers of migratory birds, for most years. The variation between years was wide. For example, while the strong head-wind exponent-transformed coefficient in 2012 was estimated at 2.4, it was estimated at 0.05 for the following year. Furthermore, the numbers of migratory birds observed were lower during the early weeks of each season, with the exponent-transformed regression coefficients remarkably smaller than 1 .

Figures 5A and 5B illustrate how the Poisson model performs for one year's $(2010,2011)$ migration, given the weather regression coefficients of another year (2011, 2010, respectively). The median of 10000 simulated migration counts fitted fairly well to the actual total migrating bird count observed, irrespective of the number of observation days. However, the variation converged very slowly. Figures 5C and 5D were created, using weather data of 2009 to model the migration in 2010 and vice versa. Although the migratory bird counts on a 'standard day' in 2009 and 2010 were estimated to be similar and the regression coefficients were similar (Table 3), the model either severely underestimated (Figure 5C) or overestimated (Figure 5D) the migratory bird counts.

\section{Discussion}

We showed that to obtain very precise results with $95 \%$ probability from bird migration, almost all days are needed for observation during the migration season. However, if more error is allowed, a lower number of days may be needed. If an error level of $\pm 50 \%$ of the observed number of migratory birds is accepted, the observation should cover at least $50 \%$ of the days to estimate the total number of all species. If the target is to estimate the migratory bird counts for certain species for which the migration time window is known, observation can be focused on that time. For example, if we are interested in migration of golden eagles $(A q-$ uila chrysaetos (L.)) in Åland, we need to make observations during their migration period from mid-September to November. The more specific question we ask and the smaller number of indi- viduals we target introduce further randomness and uncertainty. For example, single species such as the common crane (Grus grus (L.)) may undergo very concentrated peak migration that varies over the years. Thus, it may be difficult to estimate how many days are needed for accurate counts and how to schedule this effort. This was shown in our results, where the same accuracy for the migratory sums of all species needed $15-20 \%$ less time than for crows and $30-40 \%$ less than for finches. When we summed up the counts for all species, these daily sums were much more evenly distributed throughout the migration season than for single species or species groups. To model single species migration and extrapolate over unobserved time there usually are several days with zero numbers of migratory birds in the daily observation data. For these types of data, zero-inflated Poisson regression or a negative binomial model could be more precise than Poisson regression.

If we assume a migration season of 3 months from mid-August to mid-November, it contains eight 14-day periods. This yields approximately 45 days of observation required to expect an estimate to be within the $50 \%$ error margin and 60 days for the $30 \%$ error margin of the numbers of migrating birds observed. If consecutive days are used, approximately $20 \%$ more days are needed. One consecutive period may save travelling time and cost compared with separate days.

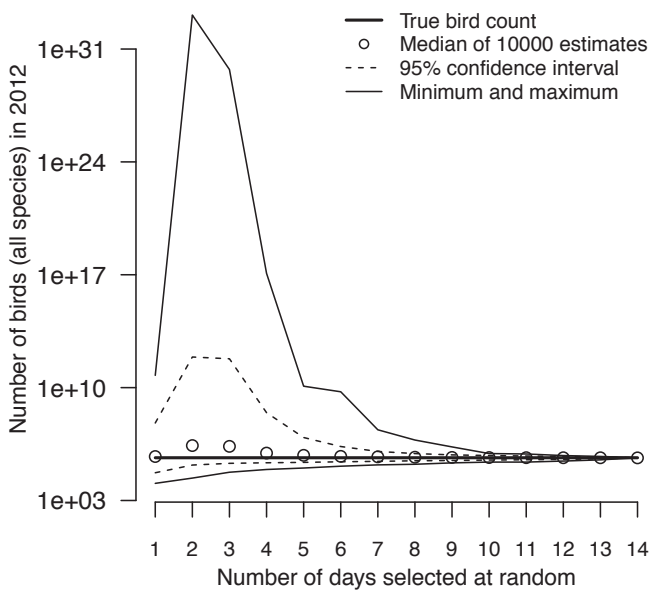

Figure 4. Results from simulating 140000 stratified random samples estimating the number of migrating birds (all species) in 2012, based on Poisson regression models fitted to the observation day data.

Resultat från simulering med 140000 slumpvisa stickprov för skattning av antalet flyttande fåglar av alla arter år 2012, baserat på Poisson-regression för observationsdata. 

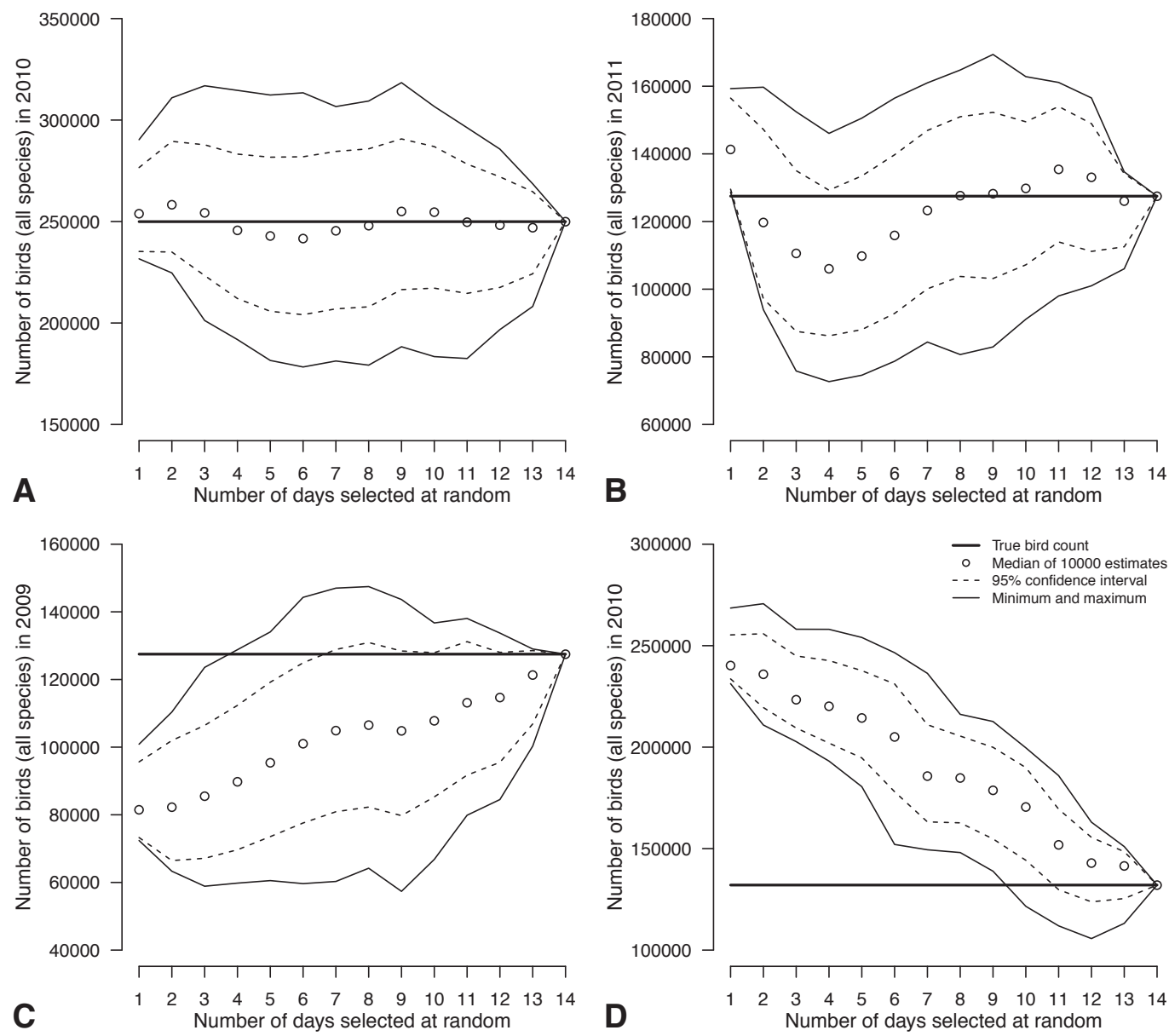

Figure 5. Results from simulating 140000 stratified random samples estimating the number of migrating birds (all species) in (A) 2010, (B) 2011, (C) 2009 and (D) 2010, based on Poisson regression models fitted to the migration data of (A) 2011, (B) 2010, (C) 2010 and (D) 2009.

Resultat från simulering med 140000 slumpvisa stickprov för skattning av antal flyttande fåglar av alla arter år (A) 2010 , (B) 2011, (C) 2009 och (D) 2010 i förhållande till observationsdata åren (A) 2011, (B) 2010, (C) 2010 och (D) 2009.

This study shows how unreliable observations of less than $50 \%$ of the time are. If reliable estimates of migratory bird numbers are needed, e.g. in EIA studies, potential migration time must be focused on intensely. This includes not only days, but also time within days. In this study, we did not focus on how many hours per day are needed, but the same principles apply. If observation is only during early morning, individual species or some of all species may be missed. Timing during the day should also be randomized to some extent, so that migration densities during the day can be estimated. In our data, the daily observation time varied and may have resulted in increased variation in the daily sums of different birds. This was due to the nature of the data. An ordinary compulsory morning session lasts three hours, but if the migration is lively, volunteers may continue to observe longer and more often than when migration is weak.

Linear extrapolation with randomly selected days yielded the best results of the methods tested. Only estimating finch migration numbers by observing continuously over several days was better. This may have been due to the uneven distribution of migrating finches within the 14-day window, since these species showed better matching to total migrating bird numbers than did even the probability for each day. The Poisson model from the observed 
data and weather data yielded very accurate results when almost all days were sampled in most simulations. In some simulations, the estimated number of migratory birds deviated strongly from the observed number when the observation days' weather and number of migratory birds did not match with those estimated, e.g. when the observation days were rainy and showed lively migration, while the remaining (unsampled) rainy days showed low migration intensity. In this case, the coefficient for the rainy days was overestimated in the model. In the third approach, weather covariate values, the coefficients modelled from the sampled days could be made for different species or species groups separately. Modelling migration for raptors and waterfowl may result in very different parameters, and combining these two or all species may produce incompatible parameters. In our example, modelling the migration of crows with weather conditions showed better fit than for finches.

We used stratified sampling with 14-day windows and equal numbers of days in each time window. The excess effort spent on days with low number of migratory may be counterproductive. Thus, more efficient results could be achieved with a sampling strategy in which more observation days are included in periods during which target species are observed in abundance. Using time windows for selecting observation days is crucial. It ensures that observations are made throughout the season and thus for all species of interest, but results in slight underestimation of migrating bird numbers, which is due to the time distribution of migration. Many birds migrate in a fairly short period, and forced observation from days of zero migration is probably the reason for this underestimation.

Linear extrapolation is a useful method when observations cover only a small portion of the entire migration season. When a larger portion of the season is covered, predicting migrating bird numbers from observations with weather data will become preferable. The advantage in modelling migrating bird numbers, using weather data, is that collecting local weather data is inexpensive with automated weather stations. The methods we used are examples of modelling, while others such as the log-linear regression model (van Belle et al. 2007) may use weather data for better estimation of the number of migratory birds and thus may reduce the number of days needed to accurately compare the methods presented here.

The impact of weather clearly varied over the years. This was at least partly dependent on some weather conditions being rarer in some years than in others. For example, if there is only one day of heavy headwind in a certain year and long periods during another year, then migratory birds can easily avoid this single day compared with the long periods. This was clearly seen in 2012, where strong migration with strong headwinds was observed and no migration with medium headwinds, in contrast to all other years.

The response to weather conditions varied between bird species. Thus, a more effective way of modelling would be to divide birds into groups sufficiently large to show similar responses to wind and rain conditions. This could be done with a separate data-mining procedure to find meaningful taxonomic groups or expert evaluation by migration observers. For most species, the number of birds observed was too small and sparse over time for weather-modelling purposes. In this study, we used weather modelling separately for crows and finches. Weather conditions may reroute migration or change its altitude. In the Signilskär area, tail-wind conditions with good visibility forced pigeons (Columba sp. L.) and Eurasian jackdaws (Corvus monedula L.) to migrate at high altitudes directly over the Sea of Åland south of Signilskär, making flocks invisible to observers on the island, but visible at Eckerö on the mainland before taking height and crossing the Sea of Åland. Many raptors use thermal-convection flows and select their routes accordingly. The relatively high migration intensity observed under head-wind conditions is thus somewhat biased, because the birds fly low at sea level, using islands when crossing the Sea of Aland. This increases the probability of an observer recording them compared with birds flying high over the open sea. When the purpose of observation is to record the number of migrating birds in a certain area, a single year's observations may not reflect the average year's numbers, and the same effort could be made more efficient when scheduled over several years instead of one.

\section{Conclusions}

To yield reliable estimates of how many birds migrated during a time period, one must observe and count the number of migrating birds on at least half of the days. Linear extrapolation results in good estimates of the total numbers when the estimation is based on only a small proportion of the total number of observation days. The larger the proportion of days covered, the better the models with weather covariates perform. 


\section{Acknowledgements}

We thank all volunteer birdwatchers, especially Ari Lehtinen and Jari Helstola for their valuable work. This study would not have been possible without their effort. We also thank two reviewers for their excellent comments and James Thompson for English proofreading.

\section{Literature Cited}

Alerstam, T. 1982. Fågelflyttning. Bokförlaget Signum. Lund. 295pp

Baker, R.R. 1984. Bird navigation: the solution of a mystery? Hodder \& Soughton ltd. London. 256pp.

Van Belle, J., Shamoun-Baranes, J., van Loon, E. \& Bouten, V. 2007. An operational model predicting autumn bird migration intensities for flight safety Journal of Applied Ecology 44, 864-874 doi: 10.1111/j.1365-2664.2007.01322.x

Berthold, P. 1993. Bird migration. A general survey. Oxford University Press. Oxford. 239pp.

Avery, M.L. 1979. Review of avian mortality due to collision with manmade structures. Bird Control Seminars Proceedings. Paper 2.

Coffin, A.W. 2007: From roadkill to road ecology: A review of the ecological effects of roads. Journal of Transport Geography 15: 396-406.

Drewitt, A.L. \& Langston, R.H. 2006. Assessing the impacts of wind farms on birds. Ibis 148: 29-42.

Fahrig, L. \& Rytwinski, T. 2009. Effects of roads on animal abundance: an empirical review and synthesis. Ecology and Society 14: 1-20.

Furness, R.W., Wade, H.M. \& Masden, E.A. 2013. Assessing vulnerability of marine bird populations to offshore wind farms. Journal of Environmental Management 119: 56-66.

Hüppop, O., Dierschke, J., Exo, K.-M., Fredrich, E. \& Hill, R. 2006. Bird migration studies and potential collision risk with offshore wind turbines. Ibis 148: 90-109.

Krijgsveld, K.L., Akerhoek, K., Schenk, F., Dijk, F. \& Dirksen, S. 2009. Collision risk of birds with modern large wind turbines. Ardea 97: 357-366.

Lucas, M. de, Janss, G.F., Ferrer, M. \& eds. 2007. Birds and wind farms. Risk assessment and mitigation. Quercus.

Smallwood, K.S. 2017. Monitoring birds. In: Perrow, M.R. (ed.) Wildlife and Wind Farms, Conflicts and Solutions. Volume 2, Onshore: Monitoring and Mitigations. Conservation Handbooks, Pelagic Publishing, Exeter, UK.

Stegman, L.S., Primarck, R.B., Gallinat, A.S., Loyd-Evans, G.T., \& Ellwood, E.R. 2017. Reduced sampling frequency can still detect changes in abundance and phenology of migratory landbirds. Biological Conservation 210(April): 107-115. Available at: http://dx.doi.org/10.1016/j.biocon.2017.04.004.
Stewart, G.B., Pullin, A.S. \& Coles, C.F. 2007. Poor evidence-base for assessment of windfarm impacts on birds. Environmental Conservation 34:1.

Ympäristöministeriö 2016. Linnustovaikutusten arviointi tuulivoimarakentamisessa. Suomen ympäristö 6/2016, in Finnish http://urn.fi/URN:ISBN:978-952-11-4624-4.

\section{Sammanfattning}

Vid miljökonsekvensbedömning av t.ex. planerad etablering av vindkraftverk behövs vanligtvis en utvärdering av risken att fåglar kolliderar med verken. För detta behövs en uppskattning av antalet fåglar som passerar området. Denna utvärdering utgörs vanligtvis av ett stickprov av tiden, till exempel delar av höstflyttningsperioden. Ett problem i sammanhanget är att det är svårt att veta hur stora stickprov som bör tas för att osäkerheten i uppskattningen skall hamna på en rimligt låg nivå. I denna studie simulerar vi hur många observationsdagar det behövs för att uppnå olika säkerhetsnivåer i beskrivning av höststräcket av fåglar och jämför olika metoder med flyttningsobservationer från Signilskärs fågelstation, Åland, Finland, från höstarna 2009 till 2013.

Hösten delades i tvåveckorsperioder och vi simulerade stickprovsförfarande med från en till 14 dagar av varje period. Proven togs antingen som enstaka dagar eller som en period av succesiva dagar. Vi använde linjär extrapolation och Poissonregression med väderobservationer som kovariat. Vi kalkylerade mot- och sidovindskomponenter för flyttfåglar enligt den vanligaste flygriktning som används i vädermodellen.

Resultaten visar att för en relativt noggrann uppskattning behövs sträcket räknas cirka $90 \%$ av tiden, och för resultat som avviker högst $30 \%$ från det verkliga antalet observerade flyttfåglar behövs det $70 \%$ till $90 \%$ av tiden räknas. Den bästa modellmetoden är linjär extrapolering då proven är under $50 \%$ av tiden och Poisson-vädermodellen då tiden är över $50 \%$ av den totala tiden. Som en tumregel ger $50 \%$ av totaltiden en felmarginal på 50\% och $70 \%$ av tiden en felmarginal på 30\%. Det är därför bättre att sprida ut samma antal observations dagar på flera år (säsonger) i stället för under en säsong, då det är stor variation mellan åren. 